\title{
Human Nature and Social Order: A Comparative Critique of Hobbes and Locke
}

\author{
Adeolu Oluwaseyi Oyekan
}

Department of Philosophy

Lagos State University, Nigeria

successcomet@yahoo.com

Thought and Practice: A Journal of the Philosophical Association of Kenya (PAK)

New Series, Vol.2 No.1, June 2010, pp.59-71

thoughtandpractice@gmail.com OR thoughtandpractice@uonbi.ac.ke

http://ajol.info/index.php/tp/index

\begin{abstract}
Central to most intellectual debates on political organization is the issue of human nature, for one's understanding of it influences one's prescriptions on how best society can be governed. This paper examines the contractarian theories of Hobbes and Locke in their attempts to identify the conditions for social order. Deploying a critical and comparative method, the paper identifies the failure of the two theories to recognize the complexity of human nature, a complexity which forecloses the plausibility of a descriptive straitjacket. The paper further argues that contrary to Hobbes' pessimism and Locke's optimism towards human nature, the individual has qualities which point to a delicate balance of both. Consequently, the paper highlights the imperatives of social order in a manner that accommodates the complexity of human nature. It concludes that it is on the basis of the appreciation of these dimensions of human nature that we can hope to evolve an enduring social order.
\end{abstract}




\section{Introduction}

The issue of human nature poses a number of problems that cut across a wide range of disciplines. At the metaphysical level, there are those who hold that man has a dual nature. For instance, Russell's reading of Plato is that Plato was of the view that there is more to the material component of man, as the physical is only a reflection of the real, or the merely manifest part of a complex whole (Russell 1947, 241). On the other hand are those who see man as a bundle of material components with nothing beyond his appearance. Aristotle and Baron Holbach evidently belong to this strand of thought. For the latter especially, man is:

... as a whole, the result of a certain combination of matter, endowed with particular properties, competent to give, capable of receiving, certain impulses, the arrangement of which is called organization, of which the essence is, to feel, to think, to act, to move, after a manner distinguished from other beings with which he can be compared. Man, therefore, ranks in an order, in a system, in a class by himself, which differs from that of other animals, in whom we do not perceive those properties of which he is possessed (Holbach 1770, 15).

As LeBuffe $(2002,11)$ explains, Holbach's naturalism requires that human nature be understood in terms of laws, and that human action be comprehended in terms of universal determinism. Nevertheless, it allows that in many ways, human beings may differ in kind from other bodies, even animals, and it allows that human beings may have many properties, notably thought, that have traditionally been denied to matter. Similarly, in his dualism, Descartes $(1984,113)$ argues that the mind as opposed to the body is a separate entity, which performs functions that cannot be described as physical.

A careful study of the positions above reveals that the dispute which has taken centre-stage at the level of metaphysics extends to the political realm. This is because our conception of what constitutes human nature and by extension the human person's place and role in the society has serious implications for social ordering. Thus in the political realm we have the anarchists, who see man as a rational being whose nature is incompatible with the oppression that society has imposed on it under the guise of government. The human person is a free being capable of living peaceably with fellow human beings of equal natural disposition, wants and drives. Consequently, unfettered freedom is the best for his/her soul (Adams 1993, 172). On the other hand, Karl Marx $(1990,13)$ has an economic view of human nature. For him, capitalism is the cause of all human woes, deriving legitimacy from the present organization of society in such a way that the economic elite's control of power and resources 
ensures it has its way. He envisages an uprising of the masses whose revolt will put economic and political control into the hands of the masses in preparation for a transition to a stateless society.

The diversity of views on human nature should by now be appreciated not only for what they assume, but also for the conclusions reached there from. As earlier alluded to, our understanding of human nature has far-reaching implications for the process of social ordering. Moreover, human nature has a prominent place in the repertoire of explanations and justifications embedded in popular consciousness. It is this consciousness that is largely responsible for the perceptions people have of their society, and it is these perceptions that directly affect their political beliefs and actions (Bell 1986, p.ix).

This paper examines the positions of John Locke and Thomas Hobbes on human nature and their implications for social order. This investigation stems from the fact that their contractarian views have had, and continue to have, profound influence on political theory and practice. Our intention is to bring to the fore the gaps in the two thinkers' assumptions, with the aim of arriving at a synthesis that comes closer to an accurate description of human nature and its implications for a well-ordered society than does either of the theories separately.

When we talk about contractarian theories, we run the risk of referring to various accounts that run parallel to one another. One is aware of the differences between what justice and order implies in Hobbes' political philosophy for instance, in contrast to that of Locke, their contractarian approaches notwithstanding. Our use of the word justice here however is not with the intention to conflate its meaning with that of social order in spite of their relatedness. What we have done is to proceed from the assumption that no society can build an enduring social order without justice, no matter how conceived, serving as its basis. It is in appreciation of this fact that scholars from the classical period to our day who are concerned with how a society should be structured have given the issue of justice a prominent attention in their thoughts. One can see this in the works of scholars such as Plato, Aristotle, Aquinas, and more recently John Rawls. Central to the issue of justice is the formulation of principles by which to govern the basic structure of society (Irele 1993, 12). However, it should be borne in mind that no pretence is here made to the effect that the two positions (those of Hobbes and Locke)represent a distillation of all contractarian theories. 


\section{Thomas Hobbes}

In his book, Leviathan (1651), Hobbes describes a hypothetical state of nature preceding the execution of the social contract. This state is governed by laws of nature. A law of nature is “ a precept or general rule, found out by reason, by which a man is forbidden to do that which is destructive to his life, or taketh away the means of preserving the same" (Hobbes 1651, 69). Beginning from a mechanistic understanding of human beings and their passions, Hobbes postulates what life would be like without government, a condition which he calls the state of nature. In that state, each person would have a right, or license, to everything in the world. This inevitably leads to conflict, a "war of all against all", and thus lives that are solitary, poor, nasty, brutish and short.

Furthermore, within the state of nature, all men are the same in power and ability, such that without a sovereign no contract can be made without considerable doubt and suspicion. By power here, Hobbes seems to be referring to the power to compel, which carries authority with it. Save for the use of might, there is no other way by which a man can compel the other to keep his word. This is the difference between justice in the state of nature and justice as Hobbes thinks it ought to be. In the state of nature, might is the criterion of order. Hobbes' preference therefore is for people in the state of nature to replace individual might with a leviathan that aggregates the might of all and exercises such on their behalf. Thus prudence has a vital role to play in Hobbes' idea of justice since men, even with all their avarice, would seek to avoid the punishment that accompanies failure to keep one's end of the bargain.

Hobbes sees justice as keeping one's valid covenants and promises. For him, there can be no contract if there is reasonable cause for either side to believe the other party will not keep their part of the bargain. The other requirement of viable covenants is the presence of a sovereign, which oversees the covenants and dispenses punishments if they are not fulfilled. Individuals in the society should attend to their own individual affairs, while the sovereign power acts to construct the framework of laws and institutions within which they pursue their private interests and "to direct their actions to the common benefit" (Hobbes 1651, 227). Thus according to Hobbes, the defining feature of a polity is the existence of an effective sovereign, that is, a more or less unified, concentrated, and exclusive center of political power and authority that stands above the society and governs it through the enactment, 
enforcement, and administration of laws. This orientation takes for granted the distinction between the rulers and the ruled, or the sovereign and subject.

One can understand why Hobbes holds that there can be no justice in the state of nature, for he believes that "the bonds of words are too weak to bridle men's ambition, avarice, anger and other passions, without the fear of some coercive power" (Hobbes 1651, 71). Without the fear of being punished, man's tendency to renege cannot be tamed. This is because he is by nature a self-seeking being. Private appetite is the measurement of good and evil (Lloyd $2008,5)$. Once a valid covenant is made between individuals who do not have reasonable cause to believe that the other is plotting against them, there are only two ways to be freed of the covenant: either by performance or forgiveness. Nevertheless, the moral shield provided by the covenant between the people and their sovereign is not extended to those not included in the contract. This includes those from other societies as well as those who cannot comprehend the contract such as the senile, imbeciles, infantile and animals.

Hobbes' conception is laced with many implications, one or two of which demand scrutiny. If merely keeping one's covenants can attain a just and orderly state, then justice allows for a lot of atrocities: it gives one the leverage to be cruel to outsiders, the naturally challenged, and even to animals since they are not part of the contract. In another vein, if Hobbes' conception of human nature is anything to go by, social order is bound to be elusive; for the sovereign himself is susceptible to all those traits which warranted the draconian arrangement, in addition to wielding unrestricted power. The case cannot be made that prudential reasons would guide him, because it is possible in all cases for the sovereign to have the means to quell rebellion. Besides, , entering into a contract with the sovereign means that one must remain loyal even when the sovereign is pursuing an unjust cause in order to avoid sanctions. Going by this logic, those who supported Hitler during the holocaust in Europe and those who killed for Sani Abacha in his bid to cling to power in Nigeria were merely living up to the terms of the covenants into which they had entered.

All in all, Hobbes' notion, stemming from his pessimistic view of human nature, is ironically excessively permissive even in its narrow conception. Man for sure has got his foibles, but he is not a beast that must be tamed at all times. 


\section{John Locke}

Locke's theory has a more optimistic view of the state of nature than that of Hobbes. For him, human nature is guided by tolerance and reason. The State of Nature is pre-political, but it is not pre-moral. Persons are assumed to be equal to one another in such a state, and therefore equally capable of discovering and being bound by the Law of Nature. The Law of Nature, which is in Locke's view the basis of all morality, and given to us by God, commands that we do no harm to others with regards to their "life, health, liberty, or possessions". Because we all belong equally to God, and because we cannot take away that which is rightfully His, we are prohibited from harming one another. Consequently, the State of Nature is a state of liberty where persons are free to pursue their own interests and plans, free from interference and, because of the Law of Nature and the restrictions that it imposes upon persons, it is relatively peaceful (Locke 1821, 182-184).

While the covenant as envisaged by Locke is also governed by reason, it is warranted not to curb the chaos that characterized the state of nature as envisaged by Hobbes, but to foreclose its possibility. Whereas Hobbes perceives men to be too perverted to keep their word without coercion, Locke sees men as being rational and capable of keeping the divine precepts guiding the state of nature. To this end, an overbearing sovereign is not needed. In its place is a government that is nothing beyond a glorified secretary. Its duty is to guarantee the rights that people already enjoy in the state of nature. Why, then, do we need a government if men are capable of living by these precepts? Government comes into being when individual men, representing their families, come together in the State of Nature and agree to each give up the executive power to punish those who transgress the Law of Nature, and hand over such powers to a public entity. The duty of that entity is to protect people's liberty.

Thus from Locke's point of view, we can only talk of social order where there is liberty, which covers, among others, the right to life and property. Commenting on Locke's position, Nigel Warburton writes:

One cannot really talk of liberty in the Lockean sense without the freedom to own property. This is because the principal motivation for leaving the state of nature is the need for protection of life, liberty and property, and especially the last of these. So strong is Locke's position that he asserts that failure of those entrusted with the protection of liberty to do their job should result in their overthrow (Warburton 1998, 4). 
For Locke $(1690,73)$, it is consent that legitimizes a government. As a consequence, failure to act for the common good is an invitation to dissolution. Securing social order through the formation of any government invariably requires the direct consent of those who are to be governed (Locke 1690, 95). Each and every individual is expected to concur with the original agreement to form such a government, but in reality it would be enormously difficult to achieve unanimous consent with respect to the particular laws it promulgates. So, in practice, Locke supposes that the will expressed by the majority must be accepted as determinative over the conduct of each individual citizen who consents to be governed at all. What this means is that what is more important than the decision taken is the fact of participation. It matters less if a particular decision arrived at say, during an election or referendum, turns out not to favour some, inasmuch as the general principle allows for their participation. We may all concur that we hold an election, but the majority has the final say as to who wins (Locke 1690, 97-98).

Although Locke offers several historical examples of such initial agreements to form a society, he reasonably maintains that this is beside the point. In other words, even if there were no historical references, membership of any society has imposed the necessary burden of consent. All people who voluntarily choose to live within a society have implicitly or tacitly entered into its formative agreement, and thereby consented to submit themselves and their property to its governance (Locke 1690, 119).

The structure of government so formed from such an agreement is of secondary importance to Locke. What matters is that legislative power - the ability to provide for social order and the common good by setting standing laws over the acquisition, preservation and transfer of property - is provided for in ways to which everyone consents (Locke 1690, 132) . As Kemerling (2008) correctly points out, because the laws are established and applied equally to all, Locke argues that this is not merely an exercise in the arbitrary use of power, but an effort to secure the rights of all more securely than would be possible under the independence and equality of the state of nature.

Since standing laws continue in force long after they have been established, Locke asserts that the legislative body, responsible for deciding what the laws should be, need only meet occasionally, but the executive branch of government, responsible for ensuring that the laws are actually obeyed, must be continuous in its operation within the society (Locke 1690, 144). In a similar fashion, he supposes that the federative power responsible for representing a 
particular commonwealth in the world at large needs a lengthy tenure. Locke's presumption is that the legislative function of government will be vested in a representative assembly, which naturally retains the supreme power over the commonwealth as a whole: whenever it assembles, the majority of its members speak jointly for everyone in the society. Thus the executive and federative functions are performed by persons (magistrates and ministers) whose power to enforce and negotiate is wholly derived from the legislature (Locke 1690, $153)$.

However, since the legislature is not perpetually in session, occasions will sometimes arise for which the standing laws have made no direct provision, and then the executive will have to exercise its prerogative to deal with the situation immediately, relying upon its own counsel (Locke 1690, 160). It is the potential abuse of this prerogative, Locke supposed, that most often threatens the stability and order of the commonwealth. We can infer that Locke envisages a just state founded on liberty, best guaranteed by the separation of state powers powers which in themselves are primarily for the purpose of securing individual liberties and property rights.

Social order from the Lockean point of view can be said to obtain when people enjoy their right to liberty, to the extent that such enjoyment does not violate the liberty of others. However, critics of Locke have argued that his theory is meant to serve the interests of the property- owning class by limiting the role of government to the protection of rights and property. His emphasis on liberty is taken to such a point that it leaves room for extreme inequalities, thereby resulting in class society. Equal right does not amount to equal capacity, and this implies that over a period of time some individuals will have more than others. The more this happens, the more opportunity they have to lord it over those who are less privileged. The tendency to maximize this advantage is what breeds inequality.

Locke also seems to think that his mechanistic notion of authority, in which all arms of government are restricted to performing the functions for which they are designed, will guarantee the attainment of liberty. Yet what cannot be ruled out is the possible connivance of the different arms to undermine those liberties. While there is some merit in the separation of powers, it does not automatically foreclose abuse. This probably explains why Locke made provision for the removal of any authority that violates the sanctity of its contract with the people. 


\section{The Gaps}

From the comparative analysis above, it is clear that Hobbes and Locke have taken two extremely different views of human nature, resulting in contrasting conclusions. Hobbes' obsession with the need for social order accounts for why he prescribed a system which gags the individual. On the other hand, Locke was desperate to uphold the sanctity of individual liberty, and incorrectly assumed that its protection would translate into an orderly society. This position stemmed from Locke's tendency to see society as no more than a collection of individuals, such that an understanding of the part is tantamount to a comprehension of the whole.

Hobbes failed to recognize the fact that the idea of a society remains absurd in the absence of individuals. It is for this reason that any political arrangement that suppresses claims to individuality in the name of the state is bound to experience disorder, as the whole does not exist in isolation from the parts. On the other hand, Locke failed to appreciate the fact that individuals coming together to form a society do so in order to prevent a degeneration into a barbaric state of nature, and that this requires the forfeiture of some of the rights that locke ascribed to man in his hypothetical state of nature.

Fundamentally, the two contractarians failed to understand that the human person is a combination of both the individual and social dimension. Today this failure lies at the heart of the sanctimonious posture of capitalist and socialist assumptions as the two contending ideologies in the world. Paradoxically, both have a rational conception of human nature to the extent that in its classical form the former, as espoused by Locke and his adherents, advocates minimum government in a bid to safeguard the individual's freedom. The latter similarly asserts that the socialist revolution will not be perfected until the state has withered away, so that people co-exist without any regulation from a political authority. If this basic conception of the human person as a being destined for freedom is shared by both Hobbes and Locke, then the question is how they arrived at divergent conclusions. The answer to this is clear: an assumption can be interpreted to suit the ideological convenience of whoever is looking at it. However, history has shown us that neither positions can, in isolation, sustainably promote the much-needed order in any society. 
On the one hand, unbridled liberty to accumulate wealth as advocated by Locke often leads to disasters such as war, recession and monumental drawbacks permeating all facets of life. This is more so in this globalised age, since the few who have the means are more likely to acquire even more for themselves to the detriment of the majority. It is not by accident therefore that such situations are often remedied by welfarist policies, even in societies where it is politically incorrect to express sympathy for interventionism. The USA of the 1930s, Europe of the Marshall Plan period and the "stimulus packages" during the current economic meltdown all provide apt illustrations of this fact.

On the other hand, rigid state regulation as espoused by Hobbes stifles creativity and the flourishing of the human spirit, seeking to make robots out of beings who are by nature dynamic, so that the system eventually implodes as a result of its internal contradictions. The idea of a supreme authority in the mould of Hobbes' leviathan, akin in a sense to the Platonic philosopher-king, is the right ingredient for a dictatorship. By grudgingly and gradually liberalising certain areas in which the state used to have absolute grip, especially in the economic sphere, China is seeking to avoid a repetition of the implosion experienced by the former Soviet Union. Thus like their Western counterparts, Chinese capitalists are becoming a common sight in many Third World countries, those in Africa in particular.

While Locke can be correctly seen as epitomizing a lot that characterizes the liberal ideology today, this does not imply that Hobbes' theory in contrast is welfarist in nature. The point being made is that Hobbes' viewpoint shares certain assumptions with some theories, which like it favour the subjection of the citizenry to an authority assumed to be best placed to manage the society on behalf of its members. This idea is evidently rooted either in a partially or totally pessimistic conception of human nature as can be seen in Plato and Hegel respectively.

No doubt the human person is a freedom-seeking being. His/her priority is self-preservation. Nevertheless, he/she recognises the indispensability of fellow human beings in the attainment of his/her aspirations, because there are bound to be cases where his/her interests are intertwined with theirs. Concerning this Lucas (1962) has noted:

The human person is a social creature because of the length of his helpless infancy, in which he is dependent on training by his fellow human beings. This training depends entirely on the learning processes conducted through language, and of necessity requiring stable groups such as the human family or 
kinship group to enable it to be carried out (Lucas 1962, 129).

\section{The Imperatives of a Social Order}

It is evident that tranquility is a necessary condition for the thriving of all other creative initiatives in a bid to foster a society well organized for the overall well-being of its members. On the other hand, social disorder is a function of the problem of social control. According to Oladipo $(1992,56)$, social control concerns the issue of the development and maintenance of social order within which individuals can exercise their rights, perform their obligations and realize their genuine human potentials. Meaningful existence therefore is contingent upon the extent to which a society is able to institutionalize frameworks that sustain the maintenance of social harmony and prevent the escalation of human conflict.

For Messner $(1949,149)$, it is the social system as well as a scheme of relations that define the political, economic and social roles, rights, duties, entitlements and objections of people in a society. In other words, social order has to do with the harmonious balancing of every strata of life to the extent that the human person is affected by them all. One should not be seen as deserving an overriding attention to the detriment of others. This is due to the fact that society thrives better when there is equilibrium in the collective matrix.

Zanden $(1997,153)$ identifies certain features of social order, without which he considers a society to be on the precipice. These include organization, regularity, stability and predictability. For him, the attainment of order must be based on an adequate apprehension of social roles. By this he means a reciprocal and systematic way of relating obligations and rights with expectations. However, it is the view of the present author that apprehension of social roles with all its importance may not be adequate for the attainment of peace and order. This is because what is apprehended must also be appreciated. In other words, not only must people understand what their obligations are; they must also value certain things as having the capacity to add meaning to their lives. For example, the Africans who worked as slaves in foreign plantations understood what their role was, but they also knew it was a role into which they were forcefully conditioned. That is why an efficient government, as part of the indispensable features of an orderly social arrangement, must strive to put in place measures that cater for the well-being of its people. 
To attempt to reel out a comprehensive list of what it takes to have social order is a herculean task. Suffice it to say that efficient systems of justice, political freedom and economic empowerment, and internal and external security are some of the things an orderly society cannot do without.

\section{Conclusion}

In this paper, we have attempted to compare Hobbes' pessimistic and Locke's optimistic conceptions of human nature and their attendant implications for an enduring social order. In exposing the shortcomings of both positions, the paper has explored the possibility of having a conception of human nature that is more encompassing than either of them. We are persuaded that this approach affords a broader and more realistic way of understanding human nature in an effort to entrench social order. It equally serves as a call for caution in the absolutisation of ideological values in a way that ignores the dynamism and complexity of the human person.

Thus the point emphasised in the foregoing reflections is that most of the individuals' desires and aspirations are not only meaningless, but also unachievable, in the absence of fellow human beings who jointly comprise the society. Innately therefore, the human person cannot be said to be a beast as Hobbes theory suggests, neither are all human beings virtuous as Locke's implies. This realisation probably accounts for why Locke considered the strong possibility of degeneration where there are no checks and balances in government.

The fusion of individual and societal interests should therefore be understood in a way that allows for a proper balance that guarantees individual expression and societal cohesion. Too much attention on the promotion of societal cohesion may lead to the erosion of individuality, just as undue promotion of individual interests may lead to anarchy (Opafola 2008, 10). Social dislocation is often the result of unregulated freedom, which leads to skewed distribution of resources and privileges in favor of the strong. The promotion of social order is therefore germane and deserving of continuous adjustment to ensure the appreciation of individual worth and the sustenance of social order. As the current global economic crisis suggests, an extremist conception of human nature is bound to lead to social disorder and a violent rupture of the tranquility which the individual desires. 


\section{References}

Bell, C. 1986. Human Nature: Issues in Political Theory. London: Macmillan.

Descartes, R. 1984. The Philosophical Writings of Descartes. Cottingham, J. et al. trans. Cambridge: Cambridge University press.

Hobbes, T. 1650 (1999). Leviathan. London: Maxfield Publishing Co.

Holbach, Baron. 2004. System of Nature. London: Kessinger Publishing. Ian, Adams. 1993. Political Ideology Today. New York: Manchester Press.

Irele, Dipo. 1993. Introduction to Contemporary Social and Political Thinkers. Ibadan: New Horn Publishers.

Kemerling, Garth. 2001. "Locke: Social Order". http://www.philosophypages.com/referral/contact.htm. Retrieved 12/12/ 2009

LeBuffe, Michael. 2002. "Paul-Henri (Baron) d'Holbach". http://plato.stanford.edu/entries/holbach

Lloyd, Sharon. 2008. "Hobbes Moral and Political Philosophy". http://plato.stanford.edu/entries/hobbes-moral/\#StaNatStaWar

Locke, J. 1690. The second Treatise on Government. http://www.constitution.org/j1/2ndtreat.htm

--. 1821. Two Treatises on Government. London: Whitmorb and Fenn.

Lucas, Eric. ed. 1962. What is Man? London: Oxford University Press.

Marx, K. 1990. Capital. Fowkes, B. trans. London: Penguin.

Messner, J. 1949. Social Ethics. London: Herder Books.

Oladipo, O. 1992. The Idea of African Philosophy. Ibadan: Molecular Publishers.

Opafola, S.O. 2008. "Human Nature and the Social Order". A paper presented at the Conference on "Personhood and Personal Identity ", organized by the Nigerian Philosophical Association, University of Calabar, Calabar, $8^{\text {th }}-10^{\text {th }}$ October, 2008.

Russell, B. 1947. History of Western Philosophy. London: Allen \& Unwin Ltd.

Warburton, N. 1998. Philosophy: The Classics. London: Routledge.

Zanden, J.W. 1997. Social Psychology. New York: Random House. 